\title{
The Concept of Being; Where There Is No Pertinence between Avicenna and Aristotle's Live Dog Better than Dead King
}

\begin{abstract}
Alireza Saati
National Technical University of Athens

In 2012, my winter in Athens began with Aristotle's Metaphysics Zeta. Among strong classical philologists, I was the only student whose understanding of metaphysics had been based on Avicenna. After a while I found myself amid audiences beforehand precluded to compromise milestones of mine. But on the contrary, I embarked to reread both of the Avicenna and Aristotle from entirely different angle again. Inquiring in the concept of Being in both of the Aristotle and Avicenna was the first candidate of my decision. This paper is the result of mentioned concern. Aristotle's equivalence between the question of "what substance is" rendered to the question of "what being is" in addition to spelling out the implications of this observation done by Avicenna-basing on his own metaphysics - constitutes the body of my paper.
\end{abstract}

Keywords: substance, Being (Existence), being (entangled existent), subject, categories, universals

Vindicating such an intriguing title asks quite enough tact audacity of knowing how far we may go without going too far. In his ground-breaking masterpiece "The Logic of Lightening (Men)," Avicenna points out to Farabi's treatise "On the Purposes of Metaphysics" by the reading of which an end is put in his deep-rooted struggle with Aristotle's Metaphysics. ${ }^{1}$ Until now, this adventure has always been interpreted in a way which curries Aristotle's favor somehow against Avicenna. In this paper, in contrast I wish to argue that Avicenna's different frame of reference does not allow us to have such conclusion. In this observation, in a court of justice, the concept of Being as the landmark of metaphysics might play the main role.

Logically at the outset, it seems absurd to assume a variety of definitions or even a definition for the concept of Being. ${ }^{2}$ But the ins and outs of the issue show us that the problem is not so simple and in spite of having fixed characterizations for the concept of Being, still from Aristotle to Mulla Sadra in Islamic philosophy, morass of questions is laid down here. Through following lines, I am going to go to the very beginning of this concept, where Being gets a marked-off concept. For fulfilling the task, I confine myself to Aristotle and Avicenna as the only two main features that are recognized for this beginning.

Aristotle's account of this subject comes up as "being' in the puzzling question of book three of

Alireza Saati, Ph.D., postgraduate program of the Philosophy of Science and Technology, Department of Humanities, School of Applied Mathematics and Physics, National Technical University of Athens, Greece; main research fields: Ancient Greek and Medieval Philosophy, Analytic Philosophy, and German Idealism (Logic, Metaphysics, and Ontology). Email: saati.philosophy@gmail.com.

The first idea of this paper was formed during the last year of my Ph.D. studies in Athens in the winter of 2012. I am most grateful to some Greek-European contemporary circles in classical philology whose excessive antipathy attitude, somehow inimical towards Avicenna benefited me to reread both of the Aristotle and Avicenna over and over again in order to discover the considerable differences and pertinences which definitely exist between Aristotle and Avicenna. Ignoring Avicenna by mentioned circles, prompted me to have inquiry into some broad topics in both philosophers. Current paper was written due to this fact. 
Metaphysics when he asks "whether and why the science that studies the axioms will also study substance, and which study will be prior to which" (1997, 996 b26-997 a15). ${ }^{3}$ While Aristotle inquires about the universal science of being, being gets passed over into substance. In the Metaphysics, he says: "and indeed the question which both now and of old, has always been raised and always been the subject of doubt, viz., what being is, is just the question: What is substance" $\left(1997,1028\right.$ b2-4). ${ }^{4}$ In this respect, the question of "what being is" has explicitly been reduced to "what substance is."

Aristotle's notion of substance known as ovoía is crucial to his Metaphysics; though this term due to using in different interrelated ways is absolutely complicated insofar as unmasking the term in Aristotelian philosophy for understanding on that what this notion indicates has always been the subject of interests and disputes. Aristotle's puzzling aforementioned shift becomes more complicated when the wandered discussion of substance firmly becomes the milestone for the exposition of being. At the beginning of Metaphysics Zeta (hereafter $Z$ ), Aristotle says:

There are several senses in which a thing may be said to "be," as we pointed out previously in our book on the various senses of words; for in one sense the "being" meant is "what a thing is" or a "this," and in another sense it means a quality or quantity or one of the other things that are predicated as these are. While "being" has all these senses, obviously that which "is" primarily is the "what," which indicates the substance of the thing. ${ }^{5}$ (1991 \& 1984, 1028 a10-14)

The curtail account of substance proposed at the beginning of Metaphysics $Z$ introduces the substance as "that which 'is' in the primary sense." As we see, Aristotle quite unequivocally, again declares that the question of "what substance is" is rendered to the question of "what being is." For Aristotle what actually exists is the world of substance, because to be is to be existent. Since hitherto, no exposition is given to being; it deserves already to see if any of either ontological or epistemological bounds support this idea. As a remark, at the outset, I would like to say that the answer is abruptly negative. Let examine why Aristotle's account of substance leads us towards such an upshot.

As Aristotle immediately drags us in the problem, pointing out into some boundary propositions concern substance by which Aristotle highlights main considerations - which the discussion is confronted with—shall drop us in the middle of controversy. In Book $Z$ of Metaphysics and elsewhere, Aristotle commits himself to the following propositions:

(A) No universal can be substance ${ }^{7}$

(B) The form is a universal; ${ }^{8}$

(C) The form is what most truly substance is. ${ }^{9}$

These three statements indicate on involving a grave inconsistency in Aristotle's Metaphysics, insofar as if their divergence and disparity to be shown argumentatively then, Aristotle's Metaphysics becomes untenable on fundamental point. ${ }^{10}$ While he speaks about substance, he introduces different candidates that might be constituting substance: "as the substrate and the essence and the compound of these are called substance, so also is the universal" (1991, 1038 b1-2). ${ }^{11}$ In the final analysis, it is only the first two that he believes can actually make sense of the "this-such" idea of a substance. ${ }^{12}$ In other words, he believes that $x$ is a substance if $x$ "stands under" the properties had by the thing that $x$ is. Underlying all properties for Aristotle is the truest sense of substance if being is to be rendered into substance; therefore this could be the truest meaning of being. But yet Aristotle drops us in the bewilderment. He asks what the substratum is. Is it matter? Is it a form? Or might it actually be a sort of compound or complex of both matter and form? 
In this extent, even if we try to give a plausible interpretation to Aristotle's expositions of substance or being ( $\tau$ o óv), Aristotle's questions lead us to a brilliant answer basing on which Aristotle's points turns around the Greek world of substance, namely the actual world which actually exists. It is due to this fact that for Aristotle to be is to be existent and since this existent is immediately divided into categories, where Aristotelian system makes sense only "what is that." But does this achievement take place in categories or could it fulfill the meaning of metaphysics as being qua being?

No. The answer is abruptly negative because being qua being as the subject of first philosophy ${ }^{13}$ should not be included in particular. Now it is in point to dare to say something bold: Even essence does not have true clear philosophical sense in Aristotle. Since Aristotle instead of "whatness" of the thing that "is," speaks about

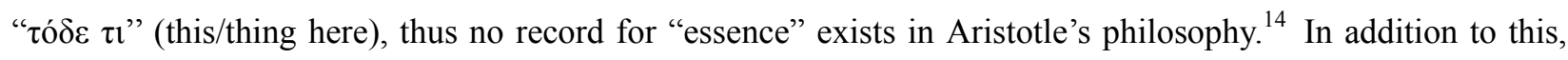
we have to notice that "essence" springs up in contrast to existence which is entirely absent in Aristotle's philosophy. ${ }^{15}$ Otherwise, Aristotle is able to deliver a clear account on being and also being qua being, whereas he does not. ${ }^{16}$ Though never Aristotle marks off any difference between essence and existence, most of the commentators and scholars have always tried to justify Aristotle by giving manifold senses ${ }^{17}$ to substance. Even if we attribute such things to Aristotle, it is a simplest and crude meaning of essence and nothing further. Aristotle account of being as "the thing that exists" cannot take place in any of categories, but Aristotle does so without taking any trouble.

The referenced block-quoted passage of Metaphysics ${ }^{18}$ is involved in different circumstances each of which advocates Aristotle's not discerning of substance different from essence and existent. This idea is bound by a key passage of Metaphysics $\Gamma$ in which Aristotle expressly asserts that "one man and a man are the same thing and an existent man and a man are the same thing" (1991, 1003 b27-29). ${ }^{19}$ What Aristotle means by this is that "the duplication in the statement that 'he is a man and an existed man' gives no fresh meaning" (1991, $1003 \mathrm{~b} 28-30) .{ }^{20}$ Aristotle not only does not reject being, but also he ignores it in getting joined with something so-called essence. He does not speak about being or even affirms it because he has no definite position concern being. In this sense, briefly I would like to claim that being (with Capital B) has no sense for Aristotle and symmetrically essence is airy and inconclusive. I do dare to claim so because anyone referred to the Islamic philosophy will see that not only Being is something sharply distinguished from essence, but also essence correspondently is wrapped up in threefold sense.

This fundamental inconsistency in Aristotle's Metaphysics is a fact which is firstly discovered by Farabi ${ }^{21}$ and is expanded then by Avicenna. ${ }^{22}$ Avicenna's philosophical debate on substance on the one hand discovering essence in its philosophical firm opens the way for him to embark towards Being establishing a new ontology sharply contrast with Greeks. Right from the beginning, Aristotle's account of substance is found by Avicenna as an unsustainable trajectory. When Avicenna sees the actual world of essences, according to him above and beyond the sensible things, it is something common in all things which are neither essence nor substance. Latin translation of Aristotle's works in an otherwise excellent way makes Avicenna's achievement clear. Real thing for Aristotle are more truly existent because their "subject is more definite, i.e., the substance and the individual" $\left(1991,1028\right.$ a26-27). ${ }^{23}$ Due to this for Aristotle, it is by reason of the substance that each of

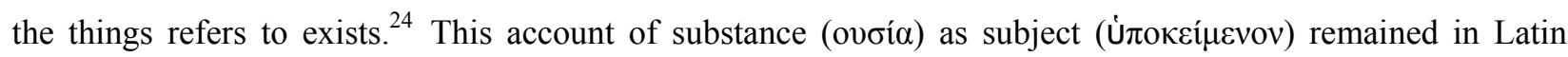
traditions till Descartes and Greek ovoía is always translated into subiectum, and in following this apparently subiectum is the same with substans throughout all medieval philosophy. Avicenna in contrast to this stream believes that what commonly is laid down behind all things is Being which is firstly applied to substance and 
then to other attributes famous as accidental categories. ${ }^{25}$ For Avicenna, every actual subject could be a substance because it stands under (sub-stare/Jacere) something else which is accident. ${ }^{26}$

In this relation, if we concentrate our investigation only on the relation between Being and substance, in his important passage of Shifa, Avicenna speaks about this relation at two levels in which a priority and a next coming (both concern Being) are included. Avicenna sets forward this crucial conclusion in order to say that being is not substance first removing metaphysical precludes then, for proceeding towards his ontology for constructing the metaphysics of Being. One of the most important points for clarifying this priority and next coming of Being — which is accepted by most of the Islamic philosophers-is Khwaja's ${ }^{27}$ commentary on Al-Isharaat (in response to Fakhr-o-ddin Razi that says: "certainly Being proceeds on essence in external (world) and is later-comer in intellect" (1375 S.H., 1201-1274). ${ }^{28}$ And Mulla Sadra immediately in continue proceeds to say that "the external preceding of Being is the root and principle of being and in intellect precursor means acting of Being" (1981). ${ }^{29}$ All explanations make Being something entirely different from essence. In relation to this, Avicenna in his very simple exposition about Being declares that "Being in itself is neither essence nor a part of essence of a thing, rather, essence is prone to Being" $(1363,61){ }^{30}$ Now, the main important point is that we find that the evasive aporia concern defining substance as what exists does not insist. In this observation in Aristotle no narrow squeak, however, is provided because defining substance as that which "is" explicitly begging the question, ${ }^{31}$ a kind of fallacy which could be solved by no way. According to Avicenna essence for coming into reality needs something else which could not be find in the context of reality but is discovered analytically, and he himself says that concern prone essence to being any other option could not be imagine and even it is not vice versa because in this case essence should be existed before its existence, and it is not possible because it is again begging the question and fallacy" ${ }^{\prime 32}$ where Aristotle drops in, I believe.

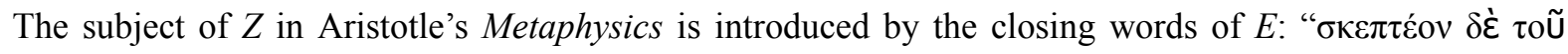

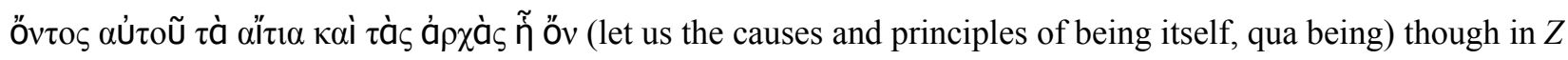
itself the emphasis is rather on the öv itself; the opening of $H$ resembles the close of E, but with $\tau \tilde{\omega} v$ oỦ $\sigma i \tilde{\omega} v$ for

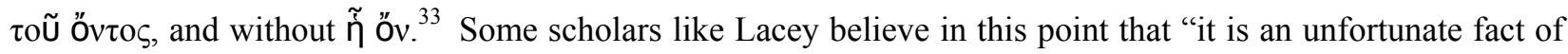
English that the termination '-ing' can be used as either participle or gerund, and so we do not know, when őv is translated being, whether the notion is meant or that which is. The use of the neuter adjective or participle for the notion allows a similar ambiguity concerning öv itself. In contrast to Lacey, I believe that not discerning the problem of Metaphysics is the poverty of classics and not corresponded languages, because even the Greek text is ambiguous. Aristotle's problem concerning being is enrooted not in language but philosophical analysis, an analysis which has no distinct record in Greek philosophy before Aristotle. ${ }^{34}$ It is in this line that $\tau$ o ö $v$ for Aristotle is $\tau \iota \varepsilon \sigma \tau i$, as if $\varepsilon \sigma \tau i$ without $\tau$ l has no meaning for him. But for Avicenna after discovering this meaning of Being, since this meaning of Being equivocally exists in all things, Avicenna announces it as a notion "common in everything" and then takes it as the same with one.

Avicenna's himself notices that "since unity does not get separate from its subject, thus the integral/inherent common predicate is derivate from this simple meaning and necessarily it is inseparable from its subjects and this is the simple meaning of accident" (1404). ${ }^{35}$ In this sense, being is discussed truly as an accident, but as the philosopher clarifies, it is not categorical accident. Due to the necessity of unity for its subject and naturally for being, being in this sense is an accident but out of predicate. This is the matter that has caused Averroes' misunderstanding of Avicenna's account of Being and then misleading of European medieval philosophical thought. Not finding out the different meanings of accident as Avicenna says, leads Averroes to 
think that according to Avicenna Being has been settled in one of the nine accidents. ${ }^{36}$ But what Avicenna says is what I cited before: The concept of Being is not possessed upon any essence and is not of implications and innate of any essence. Thus, in relation to essence, it is external, and so its predicating upon essence is accidental. What Averroes says implies being to be something out of mind to which all categories are prone. This is exactly what Avicenna does not say. Avicenna finds Being something common in everything that exists such as $\mathrm{X}, \mathrm{Y}$ and $\mathrm{Z}$ that is to be said that "X exists" and so on. In this way, Being as existence stands out by necessity with no difference in meaning in predication. Being is necessity in both of the propositions and beings, exactly like unity and one.

In the Elahiaat ${ }^{37}$ of Shifa at the end of the third article — chapter two, Avicenna states that "One is entirely equal to Being, in the sense of being predicated of any of the categories, as (when) they are predicated of Being, but their notions as you knew are different from each other, (though) ${ }^{38}$ both concepts are united and concurred in the direction of having no indication on the essence and substance of any of the categories." This emphasis can be seen all throughout Avicenna's philosophy. From his standpoint, it is stipulated that two concepts of the one and Being are not any of ten categories, thus they are neither accident nor essence and even nor substance. In this regard, the concept of Being stands in contrast to essence because essence including substance and accidents is the divisional point of ten categories, and Being is Being without any attachment.

This is what Aristotle does not see: existence beyond categories. For Aristotle the thing that is in the context of reality even weak in spelling out the philosophical implications is more real than whatever he cannot see. Without being a positivist perhaps he regards Being as dead lion and instead is delighted by tightly keeping his live dog of reality. I personally believe that Avicenna begins where the firmament of Aristotle's Metaphysics finishes. When Avicenna reads Aristotle, it is due to such reasons that even after 40 times reading of Metaphysics he says that Aristotle's Metaphysics is not understandable, not because of difficulty but of ambiguity. ${ }^{39}$ Despite the fact that Aristotle's Metaphysics indeed is one of the most important masterpieces of the history of western metaphysics, today's current text of Aristotle's Metaphysics either to be Aristotle's notes collected by the scholars or lessons; I believe that Aristotle's book, namely Metaphysics — without considering Avicenna-is no doubt problematic and complicated in content and structure. ${ }^{40}$

\section{Notes}

1. The Logic of the Orientals (Though I wish to translate it as "The Logic of the Lightening Men"), part: c, Cairo: 1910-Beirut: 1982, quoted by Ibn Abi Usaibia, Ibn Khollakan and Al Qafti: Avicenna himself expresses that "I read Aristotle's Metaphysics 40 times and I memorized all the text entirely, but I didn't understand its content. One day in booksellers' bazaar one man with insistence sold me a book. Later I found that the book was exposition of Aristotle's Metaphysics written by Abunasr Farabi. After reading that, I well-understood the concept of Aristotle's book."

2. Philosophically it is certified that the concept of Being is not definable because it is very clear.

3. Meta., 996 b26-997 a15.

4. Meta., 1028 b2-4.

5. Meta., 1028 a10-14.

6. There are several senses in which a thing may be said to "be," as we pointed out previously in our book on the various senses of words; in one sense the "being" meant is "what a thing is" or a "this," and in another sense it means a quality or quantity or one of the other things that are predicated as these are. While "being" has all these senses, obviously that which "is" primarily is the "what," which indicates the substance of the thing (1028 a10-14).

7. Meta., 1038 b8-9.

8. Meta., 1034 a5-8, in which the content more less is identical with Meta., 1038 b11-12: "man is universal," and Meta., 1036 a28. 
9. Meta., 1032 b1-2, 1033 b17, 1037 a27 ff., 1041 b6, 1050 b2.

10. I am not going to go to the details of the relation among form, substance and universals. I only loan the content in order to use it for having more clear understanding about substance in Aristotle's Metaphysics.

11. Meta., 1038 b1-2.

12. Meta., 1038 b2-5.

13. Прí $\alpha$ $\Phi$ ìобофía.

14. For more details cf. Edwards, P., Encyclopedia of Philosophy, Metaphysics, History of (Metaphysics), written by Hancock, R., The writer truly claims that in Aristotle's Metaphysics there is no difference between "what a thing is" (whatness) and that it is (thatness)

15. In this respect, none of the scholars who insist on defending the identity of essence in Aristotle's philosophy have right. For instance, look: Aristotle on the "Identity of Substance and Essence, Hartman, Edwin," The Philosophical Review, 85. 4 (1976): 545-61.

16. As an argument for this, I refer the scholars to different subjects of metaphysics introduced in different books of Metaphysics as below:

Knowledge of First Causes (Meta. A, Ross, 114)

Substance (Meta. 1)

Unmoved Substance (Meta. E)

Being qua Being (ôv ก̃ őv) (Meta. Г 1003 a)

For more analysis cf. Heidegger, M., Corpus 26, Metaphysical Foundations of Logic, 1978, 12.

17. Quiddity, essence - subjectum or suppositum. It is the fact I will deal with in the following lines.

18. Cf., the beginning of Meta. Z.

19. Meta. $\Gamma, 1003$ b27-29.

20. Ibid., 28-30.

21. For the economy of time and coherence of subject, in this paper I give up to discuss Farabi.

22. Scholastic philosophy attributes the distinction entirely to Avicenna.

23. Meta., 1028 a26-27.

24. Ibid. 25-30.

25. Cf., Avicenna, Shifa, Elahhiat, 1960, 34-35.

26. I give up having overlooking on meanings of accident but it is necessary to hint that Avicenna himself clarifies the meaning of accident as follow: "the late logicians believe that this accident is the accident which is opposite of substance. But this accident is not of that kind at all. Rather, the meaning of this accident is the accidental. Avicenna, Isharat, Vol. 1, 198. Trans. Inati, 68. He speaks about to meanings of accidents, namely isagogic and categorical. What he means here is the former one.

27. Khwaja Nasir-o-ddin Tusi (1201-1274).

28. Khwaja Nasir-o-ddin Tusi (1201-1274), Commentary on Al Ishārāt, Vol. 3, 39, also cf. Mulla Sadra, Shavahed, 13. For more details concern this cf. Avicenna, A'tta'lighāt, 185, Al Ishārāt, Vol. 3, 31, Al Mobahithāt, 275, Mulla Sadra, Asfār, Vol. 1, 47-48.

29. Mulla Sadra, Ibid. Mulla Sadra says about this as below: (Therefore he means that certainly the external existent is an objective reality originated from the Creator (generator=ja'il) and essence follows it and in mind (is) for human intellect that credits the essence abstracted from its attaching with/ to Being (concreted to the existence), by which then gets described).

”فلمر اده ... ان الوجود فى الخارج اصل صادر عن الجاعل و الماهيه تبع لهو في الذهن للعقل ان يعتبر الماهيه مجرده عن انضمامها بالوجود ثم يصف بها،

30. Avicenna, Isharat, 61.

31. Petition principii.

32. Avicenna, A'tta'lighaat, 186.

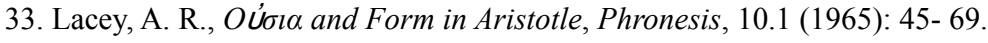

34. Except in Plato's Sophist in which the question of being is remained a open question without obvious answer, though I believe Plato does so overtly and on purpose. Before him even Parmenides "one" is material. Cf. Coplestone, History of Philosophy, Vol. 1, Greece and Rome, New York: Doubleday, 1993, 48-52.

35. Avicenna, Shifa-Elahiyat, third essay, third chapter.

36. Averroes understanding has influenced western traditions from medieval thought to some of the contemporary philosophers and scholars, for example Etienne Gilson.

37. الهيات(Theology).

38. In Avicenna's text the corresponded word is "but."

39. Cf. footnote 5 .

40. Concern structure of the Metaphysics, however, there are several ways by which scholar could be armed to discern the priority and next coming of each chapter and book.

\section{Works Cited}

Aristotle. The Complete Works. Ed. Barnes, Jonathan. Princeton: Princeton University Press, 1991. 
---. Metaphysics. W.D. Ross. 2 vols. Oxford: Clarendon Press, 1924. Reprinted 1953.

---. Aristotelis Metaphysica. Ed. Werner Jaeger. Oxford: Oxford University Press, 1957.

Avicenna. Al Ishārāt, with Commentaries of Tusi and Razi. Qom: Daftar Nashr Al Kitab, 1375.

---. Al Ishārāt, Hasan Malek Shahi, Tehran: Soroush, 1363 (Solar Hijri).

---. A 'tta 'lighāt. Beirut: rprt. Qom: Maktab Al' alam Islamiyah, 1404.

---. A'tta 'lighāt. Seyyed Hosein Mousavian, Tehran: Iranian Institute of Philosophy, 1392 (Solar Hijri).

Avicenna. Shifa, Elahi'yat. Qom: Tablighāt Islami, 1404, 1376 (Solar Hihri).

Beere, Jonathan. Doing and Being. Oxford: Oxford University Press, 2009.

Gilson, Etienne. Being and Some Philosophers. 2nd ed. Toronto: Pondificial Institute of Medieval Studies, 1952.

Goichon, A. M. Lexique de la Langue Philosophique D’Ibn Sina (Avvicenne). Paris: Desclée de Brouwer, 1938.

---. La Distinction de L'Essence et de L'Existence D'Après Ibn Sina (Avicenne). Paris: Desclée de Brouwer, 1937.

---. La Philosophie D'Avicenne et son Influence en Europe Médiévale (The Philosophy of Avicenna and its influence in Medieval Europe). Delhi: Motilal Banarsidass, 1969.

Lacey, A. R. Oúcía. And Form in Aristotle, Phronesis 10.1 (1965): 45-69.

Leher, James. Aristotle on Forms, Substance and Universals: A Dilemma, Phronesis 16.1 (1971): 169-78.

Mulla Sadra. Asfaar. 3rd. Beirut: Daro Ehya A' Torath Alarabi, 1981.

---. Shavāhed A'roboubiah. Javad Mosle. Tehran: Soroush, 1366 (Solar Hijri).

---. Shavāhed A'roboubiah, Ashtiani, Mashhad, 1346.

---. Ta 'lighat to Shifa. Tehran: Bidār, n.d.

Owens, Joseph. The Doctrine of Being in Aristotelian Metaphysics. Toronto: Pondificial Institute of Medieval Studies, 1951.

Oxford Latin Dictionary. Oxford: Oxford and Clarendon Press, 1968.

Ross, David. Aristotle. 6th ed. New York: Routledge, 1995.

Smith, J. A. "Tode ti in Aristotle." Classical Review 35 (1921): 19.

Wedin, Michael. Aristotle's Theory of Substance: The Categories and Metaphysics Zeta. Oxford: Oxford University Press, 2000.

Witt, Charlotte. Substance and Essence in Aristotle: An Interpretation of Metaphysics VII-IX. Ithaca: Cornell University Press, 1989.

Woods, Michael. "Problems in Metaphysics Z, Chapter 13." Ed. J. Moravcsik. Aristotle: A Collection of Critical Essays. New York: Anchor, 1967. 215-38.

---. "Substance and Essence in Aristotle." Proceedings of the Aristotelian Society 75 (1974): 167-80.

---. "Particular Forms Revisited." Phronesis 26 (1991a): 75-87.

---. "Universals and Particular Forms in Aristotle's Metaphysics." Oxford Studies in Ancient Philosophy, Suppl. Vol.: Aristotle and the Later Tradition. Oxford: Oxford University Press, 1991b. 41-56. 